University of Thi-Qar Journal Vol.12 No.3 SEP 2017

Web Site: https://jutq.utq.edu.iq/index.php/main

Email: journal@jutq.utq.edu.iq

\title{
Pathological changes in two species of aquatic birds result from infection with some respiratory trematodes in Al-Hamar marsh / Thi-Qar province \\ https://doi.org/10.32792/utq/utj/vol12/3/16
}

\section{Nothiala R. Al- Kasar, Mahdi M. Thuwaini* College of Nursing, University of Thi-Qar; Email: nothialarasheed@yahoo.com}

\begin{abstract}
Aquatic birds can be infected with internal parasites that may cause health problems . In the present study, Histopathological studies have been made to access the extent of damage caused by infection of some of aquatic birds with some species of Cyclocoelidae in Al-Hamar marsh / Thi-Qar province.
\end{abstract}

Generally, the pathological changes that have certified in the lungs contain inflammation of lungs, change of color, increased in size and weight, irregular, hard in consistency, pale and yellow -white plaques on the surface, the parenchyma was edematous and purple to red in color, sometimes pale flabby with multiple focal grayish areas of consolidation, and occasionally with hemorrhagic foci. Fibrosis appeared as patched irregular areas with clear distinct borders with adjacent normal lung tissue. Other lungs showed significant edema with sub pleural patches of hemorrhage, which may occupy all lung lobes with proliferation it's lining epithelium cell, areas of pulmonary fibrosis, hyperplasia of bronchus lining epithelium cells, hemorrhage with sloughing parts of epithelium in the bronchus lumen, new blood vessels(angiogenesis). Conversely, The changes that have confirmed in the liver of some infected birds include, grossly; the livers have a nodular or granular appearance with dark lesions. When incised, these lesions usually contain clear, viscous, or pale yellow fluid. identical lesions also found inside hepatic parenchyma.

Meanwhile, the histopathological changes include consolidation, rupture of hepatocytes. fibrinous of hepatic interlobular septi, Severe infiltration of inflammatory cells, hepatic fatty degeneration, necrosis of hepatic cells, hepatic cells vacuolation and degeneration. 


\section{University of Thi-Qar Journal Vol.12 No.3 SEP 2017 \\ Web Site: https://jutq.utq.edu.iq/index.php/main Email: journal@jutq.utq.edu.iq}

Keywords: Trematodes, Cyclocoelidae, Aquatic birds, Histopathology. Introduction

The parasitic infections lead to chemical and mechanical damages to the organs of theier hosts(Soulsby, 1968). Death or Considerable health problems such as defects in metabolism, growth, reproduction may cause by parasitic worms infection. The pathological effects which were resulting from parasitic worms infection varied in their severity due to different species of parasites (Bakker et al., 1997;Barber and Wright, 2006;).

The presence of worms, their movement and releasing of their toxic products in their final hosts may lead to , bleeding, scratch, inflammation and destruction of tissues and organs as well as the body's immune system may affected and introduced to secondary infections with other pathological causes (Lafferty and Shaw, 2013; Maizels et al,2014).

Infection with Cyclocoelidae members lead to some pathological effects on infected birds therefore these birds showed a gross lesions and histological changes in their organs and tissues (McLaughlin, 1977; Feizullaev, 1985; Al-Tameemi,2013).

The passage of Cyclocoelum mutabile in a different tissues and organs during their migration from the intestines to the respiratory system, especially the liver, lead to damage of these tissues and organs (McLaughlin ,1977).

Scott (1980) observed that a macroscopic pathological changes caused by Typhlocoelum cucumerinum cucumerinum differ from those caused by $T$. cucumerinum sisowi, and she showed that the large number of $T$. cucumerinum in the respiratory passages of the ducks lead to the blockage of these passages and the death of the birds as a result of suffocation and hypoxia.

Feizullaev (1985) pointed that the seriousness of Cyclocoelidae family lies in the mechanical damage caused by migration and movement of the worms inside the body of the birds, as well as collateral damage from the process of laying eggs by worms in the host's body.

Mohammad(2014) mentioned that the Haematotrephus sp cause necrosis and hemorrhage in the tissues of infected birds.

This study aims to determine the pathological changes resulting from infection of birds by Haematotrephus nittanyense, H. chengi, C. mutabile, C.microstomum and Uvitellina iraquensis. 
University of Thi-Qar Journal Vol.12 No.3 SEP 2017

Web Site: https://jutq.utq.edu.iq/index.php/main

Email: journal@jutq.utq.edu.iq 


\section{University of Thi-Qar Journal Vol.12 No.3 SEP 2017 \\ Web Site: https://jutq.utq.edu.iq/index.php/main Email: journal@jutq.utq.edu.iq}

\section{Materials and methods}

During the dissecting of 53 aquatic birds infected naturally with Cyclocoelidae, which were collected during the period from July till December 2012 from Al-Hamar marsh in Thi-Qar provinc(Table 1), The internal organs were examined grossly for any pathological changes due to parasites like fibrosis or patches spot, and recorded any damage on the surface of these organs which include liver, trachea, and lung. many specimens were taken from infected tissue, the liver and and lung which attached by parasites . After washing of these specimens with normal saline, it passed through a series of process according to Chaulan (2004), each one put in labeled glass container contains $100 \mathrm{ml}$ of $10 \%$ neutral buffered formalin at room temperature for fixation. The water had been completely extracted from fragments by bathing in a graded series of ethanol $(50 \%, 60 \%$, $70 \%, 80 \%, 90 \%$ and $100 \%$ ). The fragments were bathing in solvent xylene for clearing. Then embedding in paraffin wax. sectioning the specimens at 56 micrometers thick by Rotary microtome, clearing by melting paraffin in incubator $40 \mathrm{c}^{\circ}$ and washing in xylol. The sections were stained with Eosin and Hematoxylin stain. Mounted by Canada balsam, examined with compound microscope and photographed by digital camera.

(Table 1). Number and species of infected birds according to trematodes species

\begin{tabular}{|c|c|c|c|}
\hline \multicolumn{2}{|c|}{ Bird species } & flukes species & NO. of infected birds \\
\hline \multirow{3}{*}{1} & \multirow{3}{*}{$\begin{array}{l}\text { Chettusia } \\
\text { leucura }\end{array}$} & Haematotrephus chengi & 12 \\
\hline & & Haematotrephus nittanyense & 10 \\
\hline & & Uvitellina iraquensis & 11 \\
\hline \multirow{2}{*}{2} & \multirow{2}{*}{ Fulica atra } & Cyclocoelum mutabile & 10 \\
\hline & & Cyclocoelum microstomum & 10 \\
\hline
\end{tabular}




\section{University of Thi-Qar Journal Vol.12 No.3 SEP 2017 \\ Web Site: https://jutq.utq.edu.iq/index.php/main \\ Email: journal@jutq.utq.edu.iq}

\section{Results}

The results were appeared that Cyclocoelidae members which isolated in the present study are related to non-linked organ that parasitize them . The most isolated worms were alive and the state of constant motion. Below is a description of some of the pathological changes that have been observed when examining the organs of infected birds macroscopically and microscopically: -

\section{H. nittanyense}

The pathological changes brought about by these worms which isolated from the respiratory tract(branches of trachea and body cavity) of infected birds: macroscopically; an increase the secretion of mucus materials in the upper respiratory passages, especially in the trachea. Conversely, microscopic histological changes in lung tissue represented by expansion and congestion of the blood vessels and the proliferation of the lining epithelial cells, small hemorrhagic spots of limited areas of lung, infiltration of inflammatory cells (Figure 1) and full alveoli with inflammatory exudate. (Figure 2).However, Gross and microscopic examination of the liver showed absence of any satisfactory changes in it, except that liver parenchyma may have a nodular or granular appearance.

\section{H. chengi}

macroscopic examination of the respiratory system of the infected birds observed the presence of $H$. chengi in branches of the trachea and body cavity. It showed presence; congestion and gathering of mucous materials in the respiratory passages. Conversely, microscopic pathological changes of lung tissue of infected birds represented; thickening of lung pleura, severe hemorrhage, especially under the pleura as well as the expansion and vascular congestion and filled with inflammatory cells and thickening of the walls of the alveoli and pulmonary filling up with edematous fluids and of large areas of pulmonary fibrosis as a result of deposition collagen (Figure 3 ,4) . Moreover, Gross and microscopic examination of the liver of infected birds represented; absence of any histopathological changes.

\section{C. mutabile}

C. mutabile was isolated from body cavities and liver of Fulica atra . Macroscopically, observed gathering of mucous materials in the respiratory passages. While histological examination showed obtained sections of lung 


\section{University of Thi-Qar Journal Vol.12 No.3 SEP 2017 \\ Web Site: https://jutq.utq.edu.iq/index.php/main Email: journal@jutq.utq.edu.iq}

birds infected granite includes; severe lung edema, congestion of capillary blood vessels (Figure 5), severe hemorrhage with present of few of macrophage cells, deposition hemosiderin particles as well as fibrosis of many areas of the lungs (Figure 6,7), proliferation of the epithelial lining of the bronchi as observed with necrosis and sloughing parts of the epithelium and collects in bronchi lumen (Figure 8). Furthermore, about liver tissue of the infected birds, characterized contact area of the parasite to liver by existence of macroscopic lesion look dark as a point on the surface of the liver, as well as when incised, these lesions usually contain clear, viscous, or pale yellow fluid. Where microscopic examination appeared, existence of a Circular lesion in the position of the parasite connect the liver characterized by severe degeneration, vaculation of hepatic cells and severe infiltration of inflammatory cells (Figure 9,10) in addition hepatic septal fibrosis (Figure11) areas of hemorrhage (Figure12) and blood vessels congestion (Figure 13,14).

\section{C. microstomum}

Gross examination was observed ,congestion of airways and it appeared filling with fluids secretion. Microscopic examination of the lungs showed of the infected birds that pathological changes are concentrated in secondary bronchus, it was noted the presence of narrowing in the cavities of the secondary bronchus, thickening of the walls and sloughing parts of the it epithelium and collects in bronchus lumen blood vessels congestion, hemorrhage and peri bronchus infiltration of inflammatory cells (Figure 1518). Conversely, observed liver congestion of the infected birds. Microscopic examination of hepatic sections were showed present of irregularly shaped lesions characterized by existence of hepatic cells vaculation and degeneration (steatosis), severe infiltration of inflammatory cells inside liver sinusoids, deposition of fibrin (Figure 19-22).

\section{$U$. iraquensis}

Gross examination of the respiratory system of this birds showed the presence gathering of materials dense textures mucous in the respiratory passages. Histological sections from the lungs of infected birds examined the existence of hitopathological changes represented the development of blood vessels(angiogenesis), infiltration of inflammatory cells, increased secretion of fluids and mucus that is blue lines appear in the cavities, particularly bronchial cavities (Figure 23,24), With regard to Hepatic gross and 


\section{University of Thi-Qar Journal Vol.12 No.3 SEP 2017 \\ Web Site: https://jutq.utq.edu.iq/index.php/main \\ Email: journal@jutq.utq.edu.iq}

microscopic examination was showed the liver of infected birds absence of any histopathological changes.

\section{Discussion}

The result of the present study are similar in accordance with the studies of Lapage (1956) and Mohammad(2014) who studied the histopathology of the some internal organs of aquatic birds infected with Cyclocoelidae family members.

The severity of pathological changes of the respiratory system in Cyclocoelidae infection generally associated with activity of the worms and their movement through the respiratory tracts, which leads to mechanical damage of the epithelium lining airways and exacerbation excretion of mucous substances (Lapage, 1956). However, in the present study have been observed increased secretion of mucus and collected in the respiratory tract of infected birds, especially in $U$. iraquensis infection that caused the gathering of large amounts of mucus thick textures in cavities, justification refers to the irritation of the epithelium by the activity and the movement of the worms and their eggs. Libert, et al(2012) found eggs of Cyclocoelidae during microscopic examination of mucus accumulated in the beak of Momotus momota (blue crowned motmot) infected with species of Cyclocoelidae family in France. Al-Tameemi (2013) showed that the Haematotrephus sp left many of the pits in the body cavities of the infected aquatic birds.

However, Scott (1980) was noticed different pathological changes which happened due to infected with T. cucumerinum cucumerinum and $T$. cucumerinum sisowi which goes back to different stages of their migration. Though, T. cucumerinum cucumerinum migrate early to the trachea and stay there for a longer period, up to five months, while delayed migration of flukes $T$. cucumerinum sisowi to the trachea and migration period of survival not more than two months. Moreover, current study revealed the existence of some differences in pathological changes resulting from infection with different species of Cyclocoelidae, which has been studied and that may date back to the different ways that taking during their migration in final hosts. Furthermore, sizes differences of these worms may lead to differences in the pathological effects and severity of hemorrhage which observed in the lungs and secondary bronchi of infected birds. The severity of hemorrhage 


\section{University of Thi-Qar Journal Vol.12 No.3 SEP 2017 \\ Web Site: https://jutq.utq.edu.iq/index.php/main \\ Email: journal@jutq.utq.edu.iq}

observed in the lungs of infected birds with $H$. chengi and $C$. mutabile with a severe deposition of hemosiderin (hemosiderosis) within alveolar macrophages, which refers to the existence of severe hemorrhage, as well as pathological effects and other severe inflammatory interactions especially the presence of large areas of odema and moderated pulmonary fibrosis, which may going back to the targeting of the lungs by these two parasites and touring in it for a longer period as well as the large size of the C. mutabile compared to other species isolated in the current study.

The presence of hemorrhage in the secondary bronchus areas and in the lungs of birds in C. microstomum infection as well as pathological changes and severe inflammatory interactions which caused by this trematode in the secondary bronchus may indicate that these fluke targets these areas directly for the purpose of moving across it, or for the purpose of laying eggs. McLaughlin, (1977) noted that the worms that inhabit aleveoli for the birds coming into the lungs in order to put its eggs in the respiratory passages scattered in them. Libert et al (2012) isolated mature flukes of Cyclocoelidae family from alveoli and the area of pericardium of the $M$. momota (Blue-crowned birds ), and found the eggs of these flukes in the secondary bronchi, as well observed the presence of inflammatory interactions, dropsy (edema) and pulmonary fibrosis. Swadi, (2013) isolated C.microstomum from the lungs of C. leucura as well as from body cavities of this birds.

However, It seems that the life cycle of $H$. nittanyense, $H$. chengi and $U$. iraquensis did not include the stage of migration to the liver of the final host, absence of lesions satisfactory macroscopic or microscopic in the liver of infected birds with these three species has been observed in the current study . although there are no studies related with the life cycle and migration stages of genus Haematotrephus and genus Uvitellina in the final host, It was found that some species of Cyclocoelidae complete its life cycle in the final host without a migration stage in the liver. (Taft, 1969; Scott,1980)

The present study confirmed that the young species $C$. mutabile and C.microstomum undergo migration and roaming in the liver before continuing their way into the cavities of the body and respiratory system of birds, as noted the presence of lesions satisfactory macroscopic and microscopic lesions in the liver of infected birds, the lesions observed in the contact site of $C$. mutabile to the liver formed the circular shape while lesions 


\section{University of Thi-Qar Journal Vol.12 No.3 SEP 2017 \\ Web Site: https://jutq.utq.edu.iq/index.php/main Email: journal@jutq.utq.edu.iq}

of irregularly shaped observed in the liver of infected birds by $C$. microstomum, as well as the presence of other inflammatory interactions, this is consistent with what was said by (Ginetzinskaja, 1952) about the migration of C.microstomum to the liver and staying there for 12-15 days before settling in the alveoli of $F$. atra . However, McLaughlin (1977) showed that the young $C$. mutabile spend a period of development, ranging from 12-15 days in the liver before going to the air sacs of the $F$. atra and noted presence of a circular lesions and areas of hemorrhage in the liver of infected birds.

Fatty degeneration represents an imbalance in metabolism or convey fat which accumulate inside cells and could lead to dysfunction of the cells or in severe cases cause their explosion (Reddy and Rao, 2006). Hepatic Fatty degeneration has happening as a result of hepatitis or damage of hepatic cells by some poisons and toxins (Goudie ,1980). The fatty degeneration observed in infected birds liver by C. mutabile and C.microstomum during the current study may indicate liver injury due to the migration of those young flukes across it's tissues. Feizullaev, (1985) indicated a great damage caused by the migration of those young flukes in tissues and vital organs of the final host, especially liver because its specialized glands that excreted hyaluronidase enzyme to digeste tissues and facilitate penetration.

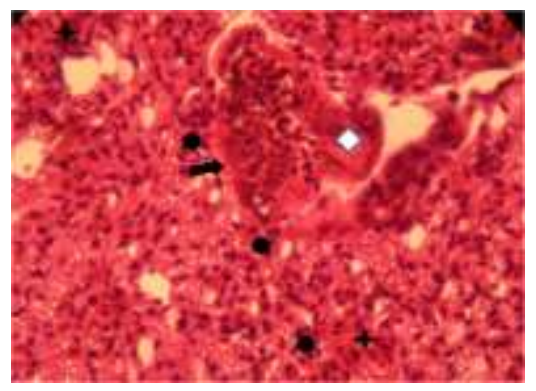

Figure 1: Section of $C$. leucura lung infected with $H$. nittanyense shows; blood vessels congestion with proliferationnt's lining epithelium cell $\diamond$, hemorrhage + and infiltration of inflammatory cells( ). H\&E.400X. 
University of Thi-Qar Journal Vol.12 No.3 SEP 2017

Web Site: https://jutq.utq.edu.iq/index.php/main

Email: journal@jutq.utq.edu.iq

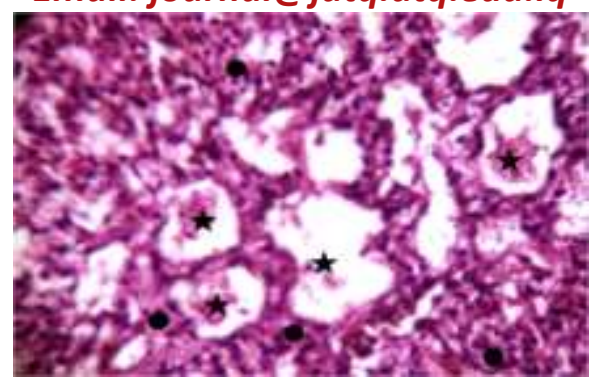

Figure 2: Section of $C$. leucura lung infected with $H$. nittanyense shows; alveoli filled with inflammatory exudate + and inflammatory cells infiltration . H\&E. 400X.

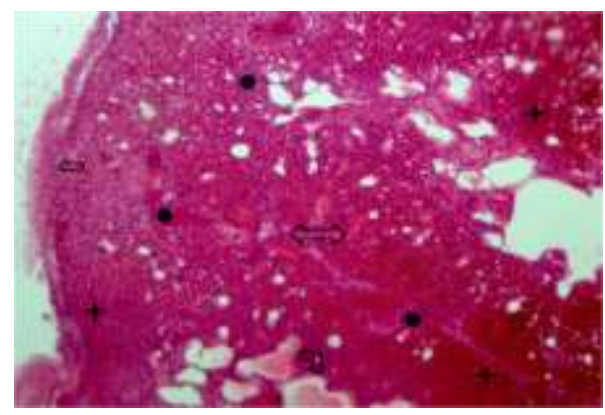

Figure 3: Section of $C$. leucura lung infected with $H$. Chengi shows: Thickening of pleura $\longleftarrow$, hemorrhage + , dilatated \&congested blood vessels $\Longleftrightarrow$, thickening of interalveolar walls \& filled with edematous fluids 包, inflammatory cells infiltration. H\&E. $100 \mathrm{X}$.

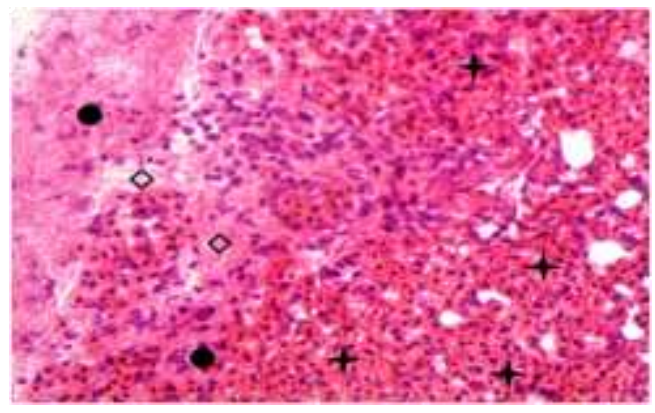

Figure 4: Section of $C$. leucura lung infected with $H$. Chengi shows; hemorrhage + , inflammatory cells infiltration - and fibrin deposition $\diamond$. H\&E.100X. 
University of Thi-Qar Journal Vol.12 No.3 SEP 2017

Web Site: https://jutq.utq.edu.iq/index.php/main

Email: journal@jutq.utq.edu.iq

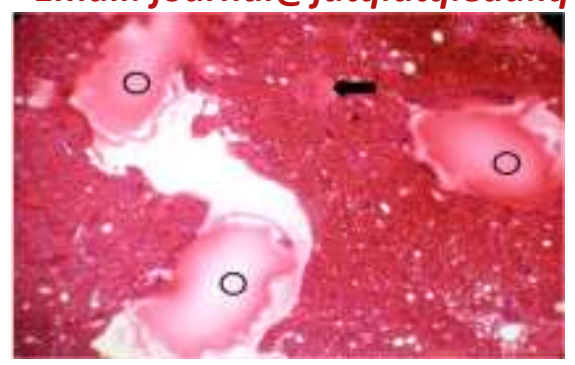

Figure 5: Section of F. atra lung infected with C. mutabile shows; edema $\mathrm{S}$, bloob vessels congestion $\quad$ H\&E. 100X.

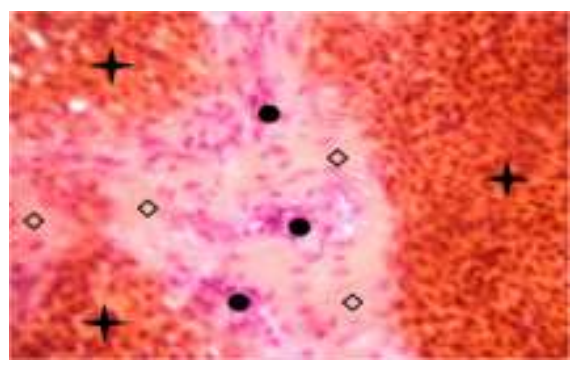

Figure 6: Section of $F$. atra lung infected with $C$. mutabile appears; sever hemorrhage + , infiltration of inflammatory cells $\boldsymbol{c}$ and areas of pulmonary fibrosis + . H\&E. 400X.

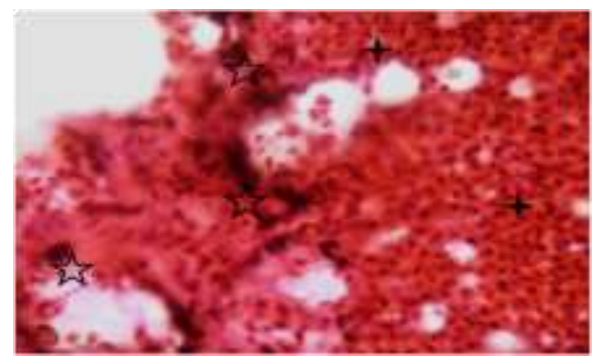

Figure 7: Section of $F$. atra lung infected with $C$. mutabile shows; severe hemorrhage + , hemosiderin deposition $\bar{k}$. H\&E. 400X. 
University of Thi-Qar Journal Vol.12 No.3 SEP 2017

Web Site: https://jutq.utq.edu.iq/index.php/main

Email: journal@jutq.utq.edu.iq

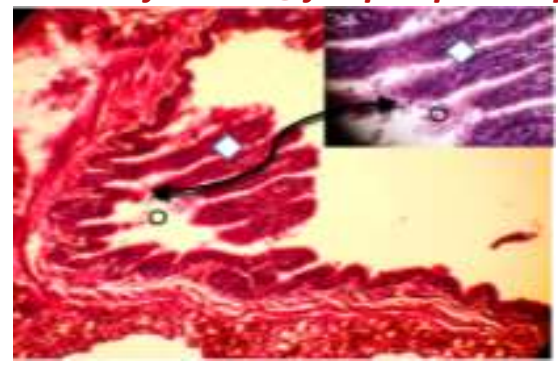

Figure 8: Section of $F$. atra lung infected with $C$. mutabile shows; hyperplasia of bronchus lining epithelium cells $\diamond$, hemorrhage with sloughing parts of epithelium in the bronchus lumen O. H\&E. 400X.

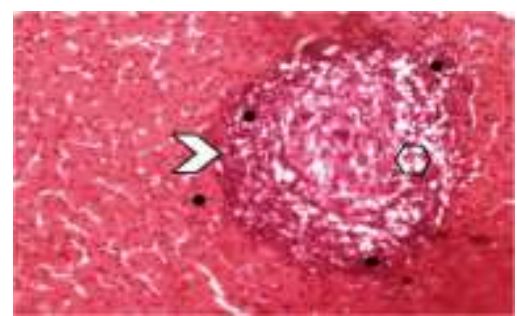

Figure9: Section of $F$. atra liver infected with C. mutabile shows; circular lesion $\nabla$, degeneration \& necrosis of hepatic cells $\square$ and inflammatory cells infiltration. H\&E. 100X.

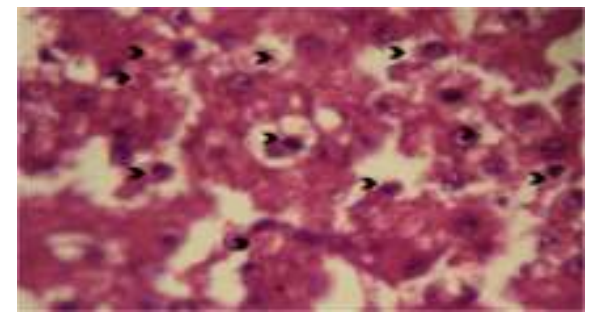

Figure 10: Section of $F$. atra liver infected with $C$. mutabile shows; severe hepatic cells degeneration \& vacuolation s. H\&E. 400X. 
University of Thi-Qar Journal Vol.12 No.3 SEP 2017

Web Site: https://jutq.utq.edu.iq/index.php/main

Email: journal@jutq.utq.edu.iq

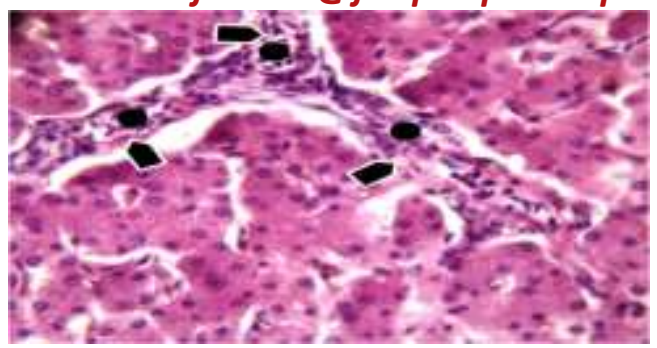

Figure 11: Section of F. atra liver infected with C. mutabile shows; fibrinous of hepatic interlobular septi , infiltration of inflammatory cells $\mathrm{H} \& \mathrm{E}$. $400 X$.

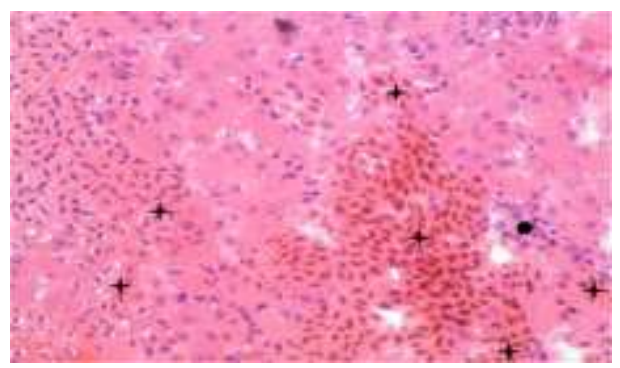

Figure 12: Section of F. atra liver infected with C. mutabile shows; areas of hemorrhage +with infiltration of inflammatory cells. H\&E. 400X.

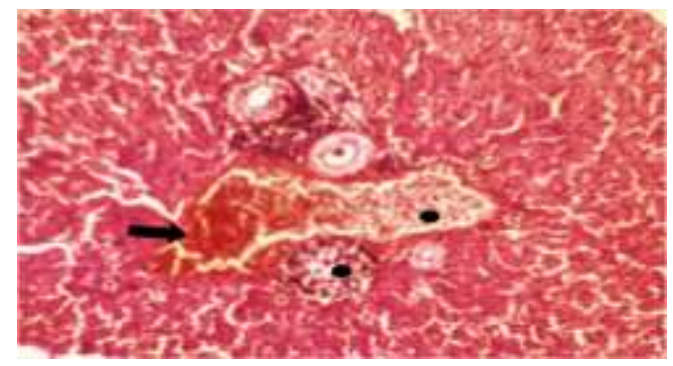

Figure 13: Section of $F$. atra liver infected with $C$. mutabile shows; congestion hepatic vein Severe infiltration of inflammatory cells - . H\&E. $100 X$. 
University of Thi-Qar Journal Vol.12 No.3 SEP 2017

Web Site: https://jutq.utq.edu.iq/index.php/main

Email: journal@jutq.utq.edu.iq

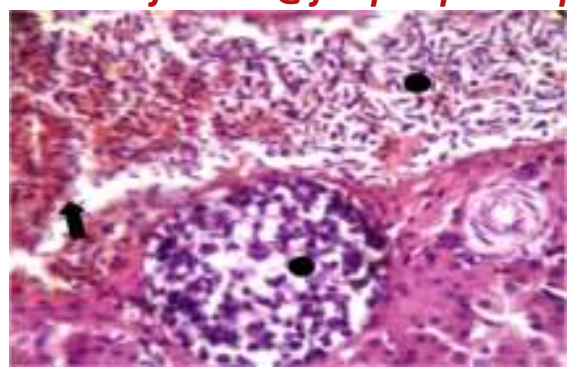

Figure 14: amplification power of above figure observe; congestion hepatic vein with severe inflammatory cells •. H\&E. $400 \mathrm{X}$.

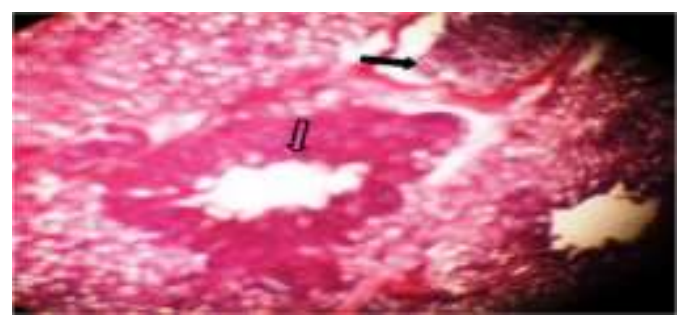

Figure 15: Section of $F$. atra lung infected with C.microstomum shows;

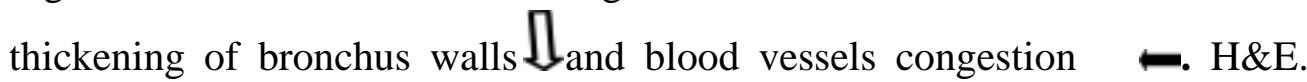
$100 \mathrm{X}$.

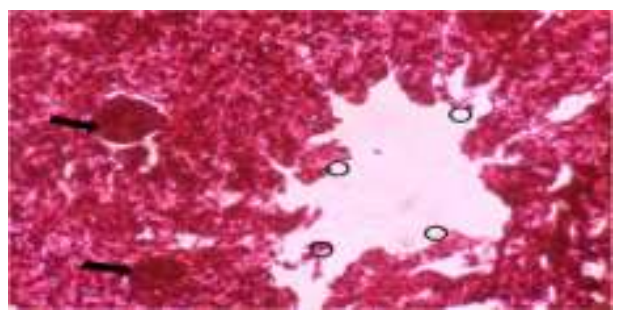

Figure 16: Section of $F$. atra lung infected with C.microstomum shows; Hemorrhage associated with epithelium sloughing lining filling bronchus cavity Oand blood vessels congestion. H\&E. 400X. 
University of Thi-Qar Journal Vol.12 No.3 SEP 2017

Web Site: https://jutq.utq.edu.iq/index.php/main

Email: journal@jutq.utq.edu.iq

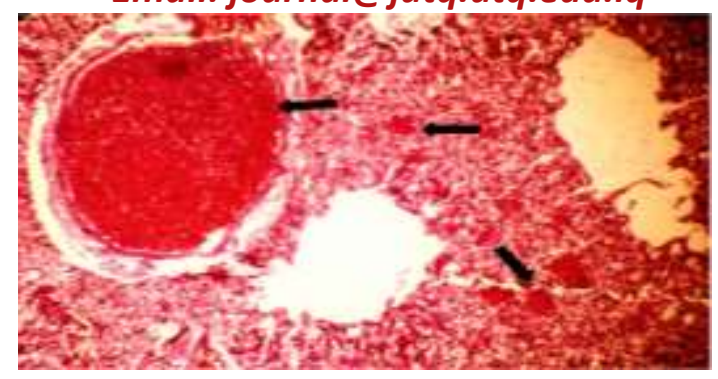

Figure 17: Section of F. atra lung infected with C.microstomum shows; congestion of blood vessels $\boldsymbol{\bullet}$. H\&E. 100X.

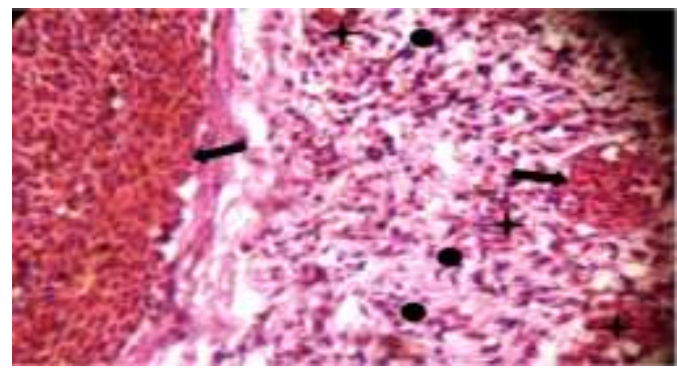

Figure 18: amplification power of above figure observe; congestion of blood

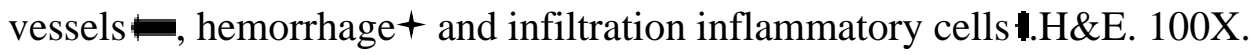

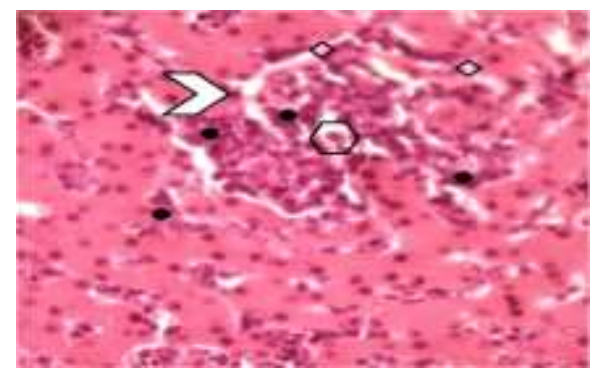

Figure 19: Section of $F$. atra liver infected with C.microstomum shows; irregular lesion $\nabla$, hepatic cells vacuolation and degeneration $\square$ fibrin

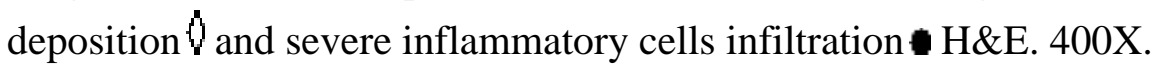


University of Thi-Qar Journal Vol.12 No.3 SEP 2017

Web Site: https://jutq.utq.edu.iq/index.php/main Email: journal@jutq.utq.edu.iq

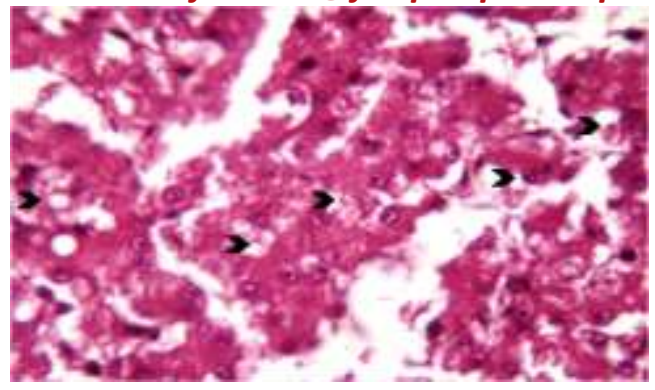

Figure 20: Section of $F$. atra liver infected with C.microstomum shows; hepatic cells vacuolation and degeneration s. H\&E. 400X.

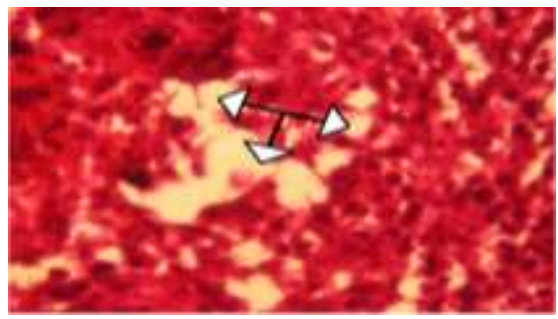

Figure 21: Section of $F$. atra liver infected with C.microstomum shows; hepatic fatty degenration $\stackrel{\leftrightarrow}{\leftrightarrow}$. H\&E. 400X.

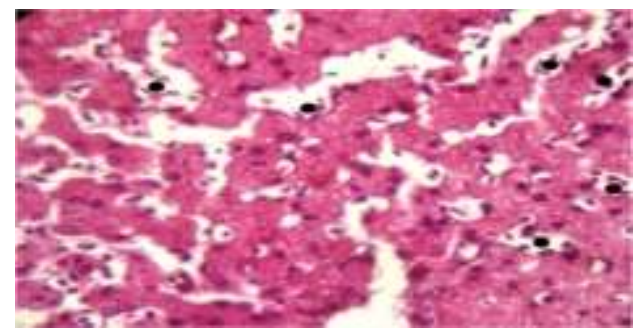

Figure 22: Section of $F$. atra liver infected with C.microstomum shows; intrahepatic sinusoids inflammatory cells infiltration - H\&E. 400X. 
Web Site: https://jutq.utq.edu.iq/index.php/main Email: journal@jutq.utq.edu.iq

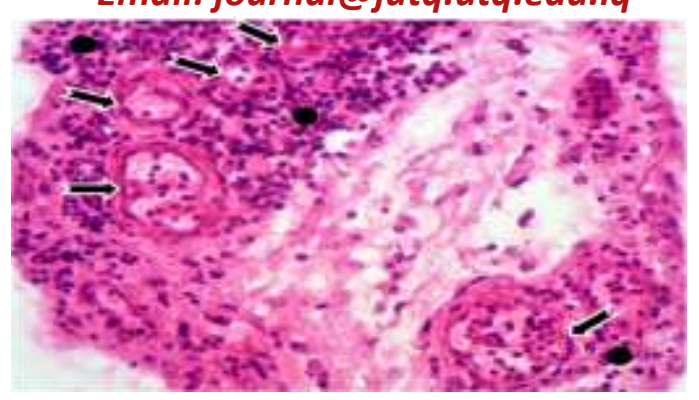

Figure 23: Section of F.atra lung infected with $U$. iraquensis shows; new blood vessels(angiogenesis) $=$ and inflammatory cells infiltration $-\mathrm{H} \& \mathrm{E}$. $400 X$.

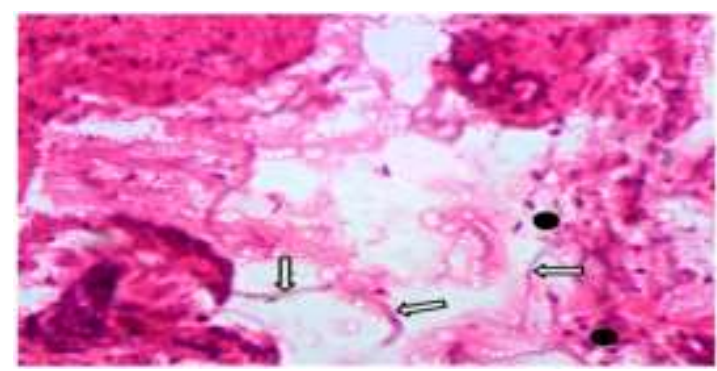

Figure 24: Section of $F$. atra lung infected with $U$. iraquensis shows; alveolar cavities filled with mixed of secretions and threads of mucus $\Longleftarrow$ ,inflammatory cells infiltration $\mathbf{.}$ H\&E. 400X.

\section{References}

1. Al-Tameemi, I. A. (2013). Helminthes parasitized on some aquatic birds \& the importance of insects in the life cycle of some of them in Basrah province. M. Sc. Thesis. Coll. Edu., Univ. Basrah: 222 pp. (In Arabic).

2. Bakker, T.; Mazzi, D. and Zala, S.(1997). Parasite-induced changes in behavior and color make Gammarus pulex more prone to fish predation. Ecology 78: 1098-1104.

3. Barber, I. and Wright, H.A.( 2006). Fish physiology and behaviour: the effects of parasites. In: Sloman, K., Wilson, R.W.,Balshine, S. (Eds.), Behaviour and Physiology of Fish. Elsevier/Academic Press: 110-149.

4. Chaulan R. S. (2004). Veterinary Laboratory Diagnosis, 1st ed. International Book Distributing Company, Lucknow: 269-285. 


\section{University of Thi-Qar Journal Vol.12 No.3 SEP 2017 \\ Web Site: https://jutq.utq.edu.iq/index.php/main Email: journal@jutq.utq.edu.iq}

5. Feizullaev, N.A. 1985. Pathogenic effect of trematodes of Cyclocoeloidea on the hosts. Parasitologia 19: 248-250 (In Russian).

6. Ginetzinskaja, T. A.(1952). Migration of the trematodes in the famil Cyclocoelidae in the final host. Dokladi Acad. Nauk , 05:1423-1426. (In Russian)

7. Goudie, R.B. (1980). Cell damage. In: Muir's Textbook of Pathology, 11th edition, pp.24-28. Edited by Anderson, J.R., London: Arnold.

8. Lafferty, K. D., and Shaw, J. C. (2013). Comparing mechanisms of host manipulation across host and parasite Can. J. Zool., 55: 274-279.

9. Lapage, G. (1956): Veterinary Parasitology, Oliver and Boyd, Edinburg and London: 1182.

10. Libert C., Jouet D., Ferté H., Lemberger K. and Keck N.( 2012). Air Sac FlukeCi rcumvitellatrema momota in a Captive Blue-crowned Motmot (Momotus momota) inFr ance. Journal of Zoo and Wildlife Medicine 43: 689-692.

11. Maizels,R.;McSorley,H.andSmyth,D.(2014). Helminths in the hygiene hypothesis: sooner or later?. Clin Exp Immunol., 177: 38-46.

12. McLaughlin, J.D. (1977) . The migratory route of Cyclocoelum mutabile (Zeder,1800) (Trematoda: Cyclocoelidae) in the American Coot,Fulica americana . Can. J. Zool., 55: 274-279.

13. Mohammad,Z.A.(2014). Ph. D. Thesis, Ectoparasites and helminthes of some aquatic birds in Al-Sanaf Marsh, Southern Thi-Qar province/Iraq. Coll. Edu.,Univ. Basrah: 222 pp. (In Arabic).

14. Reddy J.K. and Rao M.S.(2006). Lipid metabolism and liver inflammation. II. Fatty liver disease and fatty acid oxidation. Am. J. Physiol. Gastrointest. Liver Physiol. 290: 852-58

15. Scott,M.E. (1980). A comparative field and laboratory investigation of Typhlocoelum cucumerinum Digenea Cyclocoelidae in various duck and snail hosts. Ph.D. Thesis , Inst.parasitol., McGill Univ., Montreal,Canada.

16. Soulsby, B. J. (1968). Helminths, arthropods and protozoa of domesticated animals. Monning Vet. Helm. Ento. $6^{\text {th }}$. Ed. Bull. London., 824 pp. 


\section{University of Thi-Qar Journal Vol.12 No.3 SEP 2017 \\ Web Site: https://jutq.utq.edu.iq/index.php/main \\ Email: journal@jutq.utq.edu.iq}

17. Swadi, B. F. (2013). Helminthes parasitized on some aquatic birds which occupied on Shatt Al-Arab coast north of Basrah governorate. M. Sc. Thesis. Coll. Edu. Basrah. Univ., 110 pp. (In Arabic).

18. Taft,S.J. (1969). Host-parasite relationships of five species of Cyclocoelids ( Trematoda: Cyclocoelidae). Ph.D. Thesis, Iowa State Univ., Iowa,USA

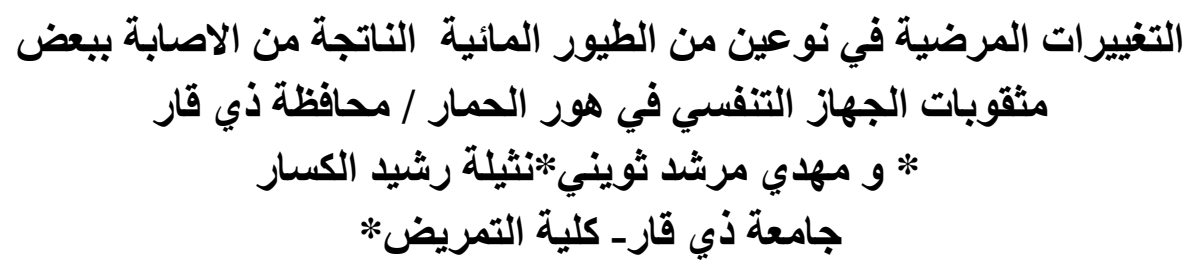

\section{E-Mail address; nothialarasheed@yahoo.com}

\section{الخلاصة}

تعاني الطيور المائية من مشاكل صحية نتيجة للخمج بالطفيليات الداخلية ـ تم في الدراسة الحالية

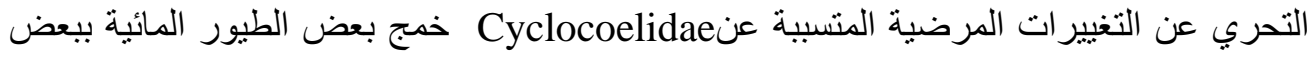

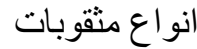
في هور الحمار / محافظة ذي قار ـ تمثلت التغييرات المرضية في الرئتين بوجود الالتهاب و تغير

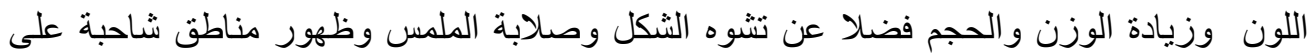

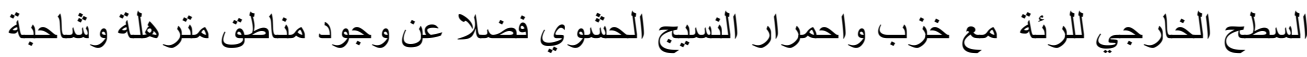

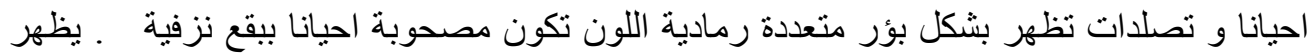

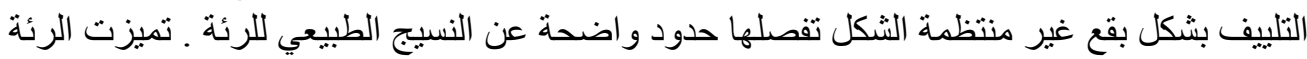
لبعض الطيور المصابة بخزب واضح فضلا عن بقع نزفية تحت الجنب وتكاثر الخلايا الظهارية

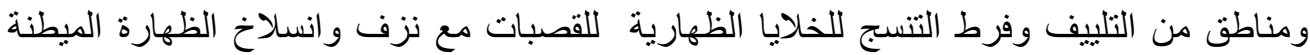

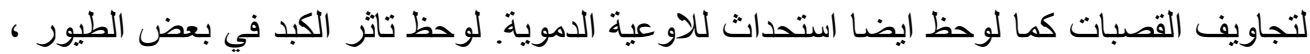

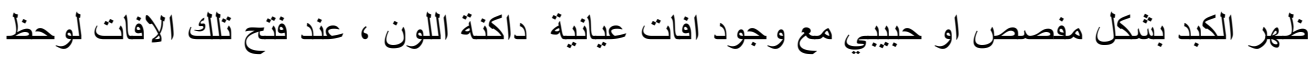

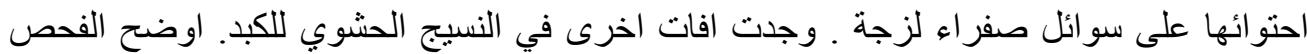

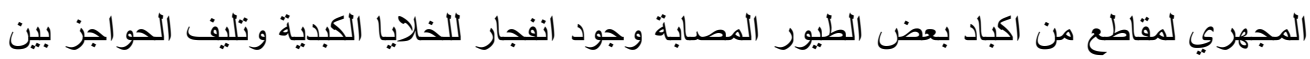

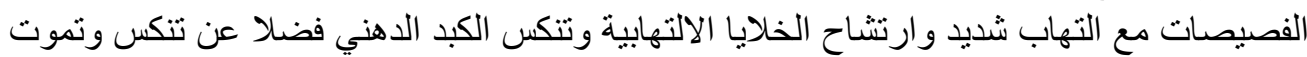
وتفجي للخلايا الكبدية. 